\title{
FAKTOR FAKTOR YANG MEMPENGARUHI PEMBERIAN OPINI GOING CONCERN
}

\author{
Muhammad Faisal Arif ${ }^{1)}$ \\ ${ }^{1}$ Dosen Akuntansi, STIEM Bongaya Makassar \\ Email : hamzahumarfaisal@gmail.com
}

(Diterima: 4 Januari 2018; direvisi:1 Februari 2018; dipublikasikan: 18 April 2018) akses terbuka dibawah licenci CC BY-NC-4.0 (https://creativecommons.org/licenses/by-nc/4.0/ ).

\begin{abstract}
:
In a standard audit it is suggested that the audit report should state whether the financial statements have been prepared according to financial accounting standard in Indonesia, and to check the degree of conformity in the audit so, the auditor should be able to obtain and consider the management plans for survival during a reasonable period of time. This research aimed to analyze the effects of the debt default, the financial difficulties, the reputation of the auditor, the previous year audit opinion, the size of the company, the shift of the auditor, and the size of audit committee on the going concern opinion.

The research samples comprised 222 company's financial difficulties, and 201 companies with the comprehensive losses observed for three year period, from 2012 through 2014. The samples were chosen using the purposive sampling technique. The research data were the secondary data ini the from of the reports of the auditor and the financial reports. The data were then analyzed using the logistic regression analysis.

The research results revealed that the debt default, the financial difficulties, the previous year audit opinion, and the size of the company had an effect on the administration of the going concern, while the reputation of the auditor, the shift of the auditor, and the size of the audit committee had no effect on the administration of the going concern opinion.
\end{abstract}

Keywords: Going Concern Opinion, and Financial Difficulties

\begin{abstract}
Abstrak :
Dalam standar audit dikemukakan bahwa laporan audit harus menyatakan apakah laporan keuangan telah disusun sesuai standar akuntansi keuangan di Indonesia, dan melihat derajat kesesuaian dalam penugasan audit sehingga auditor harus dapat memperoleh dan mempertimbangkan rencana manajemen dalam mempertahankan kelangsungan hidupnya selama jangka waktu pantas. Tujuan penelitian untuk menganalisis pengaruh debt default, kesulitan keuangan, reputasi auditor, opini audit tahun lalu, ukuran perusahaan, pergantian auditor, dan ukuran komite audit terhadap opini going concern.

Sampel penelitian ini berjumlah, 222 perusahaan kesulitan keuangan, dan 201 perusahaan rugi komprehensif dengan 3 (tiga) tahun pengamatan mulai 2012 - 2014. Teknik penarikan sampel purposive sampling., Data penelitian ini menggunakan data sekunder berbentuk laporan opini auditor, dan laporan keuangan. Metode penelitian regresi logistic.

Hasil penelitian menunjukkan debt default, kesulitan keuangan, opini audit tahun lalu, dan ukuran perusahaan berpengaruh terhadap pemberian opini going concern, dan reputasi auditor, pergantian auditor, dan ukuran komite audit tidak berpengaruh terhadap pemberian opini going concern
\end{abstract}

Kata Kunci : Opini Going Concern, dan Kesulitan Keuangan 


\section{PENDAHULUAN}

Laporan audit merupakan hal yang sangat penting dalam penugasan audit karena mengkomunikasikan temuan temuan audit. Dalam standar audit mengemukakan bahwa laporan audit harus menyatakan apakah laporan keuangan telah disusun sesuai standart akuntansi keuangan di Indonesia. Selain melihat derajat kesesuaian dalam penugasan audit, auditor harus dapat memperoleh dan mempertimbangkan rencana manajemen dalam mempertahankan kelangsungan hidupnya selama jangka waktu pantas (SPAP, 2011). Laporan keuangan tahunan yang telah diaudit oleh auditor independen akan diberikan opini going concern setelah paragraph pendapat, dimana auditor terlebih dahulu mempertimbangkan rencana manajemen dan menyimpulkan bahwa keraguan substansial atas kemampuan entitas dalam mempertahankan kelangsungan hidupnya selama jangka waktu pantas (SPAP, 2011). Kriteria untuk menerbitkan penolakan memberikan pendapat ketimbang menambahkan suatu paragraph penjelasan tidak dinyatakan dalam standart.

Menon \& Williams (2010), menjelaskan dalam penelitiannya mengapa auditor memberikan opini going concern dengan mengklasifikasikannya menjadi empat kateogri yakni, 1). Kinerja keuangan yang buruk, kategori ini mencakup kondisi keuangan dan kinerja perusahaan termasuk kerugian perusahaan saat ini atau berulang, arus kas negatif, modal kerja yang buruk, dan ekuitas negatif, 2). Masalah pembiayaan, kategori ini mencakup debt default, pelanggaran perjanjian utang, hilangnya fasilitas kredit, kebutuhan untuk pembiayaan tambahan,
3). Masalah operasi, kateogri ini mencakup hilangnya pelanggan utama, masalah dengan pemasok, dan masalah pengabungan usaha, 4). Lainnya, kategori ini mencakup litigasi dan masalah regulasi. Menon \& William (2010), mengklasifikasi ketegori pertama dan kedua sebagai kategori keuangan dan kategori ketiga dan keempat merupakan kategori non keuangan.

Chen \& Church (1992), debt default merupakan sebuah kegagalan debitur (perusahaan) untuk membayar hutang pokok dan atau bunganya pada waktu jatuh tempo. Ketidakmampuan perusahaan untuk membayar kewajibannya ketika jatuh tempo merupakan salah satu faktor yang dapat menimbulkan ketidakpastian mengenai kemampuan perusahaan untuk terus bertahan (Arens et al., 2008). Kondisi keuangan perusahaan menggambarkan tingkat kesehatan perusahaan sesungguhnya. Ramadhany (2004), pada perusahaan yang kondisi keuangannya baik, auditor cenderung untuk tidak mengeluarkan opini audit going concern. Carcello \& Neal (2000), dan Junaidi \& Hartono (2010), reputasi auditor biasanya diukur dengan membedakan KAP yang tergabung dalam Big Six dan non Big Six. DeAnggelo (1981), dan Palmrose (1988), menemukan KAP Big Six memberikan jasa audit berkualitas tinggi. Mutchler et al (1997), menemukan bukti bahwa KAP Big Six lebih mungkin dibandingkan KAP Non Big Six untuk menerbitkan laporan opini going concern kepada perusahaan yang mengalami kesulitan keuangan.

Menon \& Williams (2010), Perusahaan kecil lebih rentan terhadap kebangkrutan daripada perusahaan besar, perusahaan yang lebih besar mungkin memiliki keunggulan 
kompetitif atas perusahaan perusahaan kecil (misalnya, skala ekonomi) atau mungkin lebih mampu untuk mendapatkan pembiayaan tambahan dan menggeser sumber daya dalam rangka untuk mencegah kebangkrutan. Perusahaan biasanya menggunakan pergantian auditor (auditor switching) untuk menghindari penerimaan opini going concern. Bahwa ketika auditor tersebut independen, perusahaan akan memberhentikan akuntan publik (auditor) yang cenderung memberikan opini going concern, atau sebaliknya akan menunjuk auditor yang cenderung memberikan opini going concern. Bradbury et al (2004), komite audit bertugas membantu dewan komisaris untuk memonitor proses pelaporan keuangan oleh manajemen untuk meningkatkan kredibilitas laporan keuangan.

Hubungan keagenan di dalam teori agensi (agency theory) bahwa perusahaan merupakan kumpulan kontrak (nexus of contract) antara pemilik sumber daya ekonomi (principal) dan manajer (agent) yang mengurus penggunaan dan pengendalian sumber daya tersebut. Teori ini mengasumsikan bahwa masing masing individu semata mata termotivasi oleh kepentingan dirinya sendiri sehingga menimbulkan konflik kepentingan antara pemilik dan agen, (Jensen dan Meckling, 1976).

Dalam menyusun laporan keuangan, manajemen membuat penilaian tentang kemampuan entitas untuk mempertahankan kelangsungan usaha. Entitas penyusun laporan keuangan berdasarkan asumsi kelangsungan usaha, kecuali manajemen bertujuan untuk melikuidasi entitas atau menghentikan perdagangan, atau tidak mempunyai altenatif lain yang realistis selain melakukannya. Jika manajemen menyadari (dalam membuat penilaiannya) mengenai adanya ketidakpastian yang material sehubungan dengan peristiwa atau kondisi yang dapat menimbulkan keraguan yang signifikan tentang kemampuan entitas untuk mempertahankan kelangsungan usaha, maka entitas mengungkapkan ketidakpastian tersebut (SAK, 2012).

Debt default merupakan kegagalan perusahaan dalam membayar hutang dan bunganya yang telah jatuh tempo. Chen dan Church, (1992), menyatakan bahwa gagal bayar utang dan restrukturisasi utang telah diusulkan dalam SAS No. 59 dan No. 34 sebagai indikator masalah going concern. Menurut SAS No. 59 dan No. 34, kondisi tersebut dapat membuat keraguan substansi tentang kemampuan perusahaan untuk melanjutkan kegiatan operasional dan sebagai hasilnya, auditor harus hati hati menelitinya.

Penelitian telah menunjukkan hubungan yang positif signifikan antara probabilitas menerima pendapat going concern dan tingkat keparahan sinyal kesulitan keuangan, (Kida, 1980). Carcello et al, (1995), selain itu penelitian sebelumnya juga telah menemukan bahwa semakin besar kesulitan keuangan klien, semakin besar kemungkinan menerima opini going concern.

Reputasi auditor telah banyak digunakan sebagai indikator pemberian opini going concern karena reputasi auditor didasarkan pada kepercayaan pemakai jasa auditor bahwa auditor memiliki kekuatan monitoring yang secara umum tidak dapat diamati. DeAnggelo, (1981), menyatakan bahwa auditor skala besar memiliki 
inisiatif yang lebih untuk menghidari kritikan kerusakan reputasi dibandingkan pada auditor skala kecil. Setyarno et al., (2006), auditor skala besar jauh lebih cenderung untuk mengungkapkan masalah masalah yang ada karena lebih kuat menghadapi resiko proses pengadilan. Argument tersebut berarti bahwa auditor skala besar memiliki inisiatif lebih untuk mendeteksi dan melaporkan masalah going concern kliennya.

Dalam melakukan penugasan umum, auditor ditugasi memberikan opini atas laporan keuangan perusahaan. Pendapat atau opini audit merupakan bagian yang tidak terpisahkan dari laporan audit. Laporan audit penting sekali dalam suatu audit atau proses atestasi lainnya karena laporan tersebut menginformasikan pemakai informasi tentang apa yang dilakukan auditor dan kesimpulan yang diperolehnya. Praptitorini dan Januarti, (2007), opini audit diberikan oleh auditor melalui beberapa tahap audit sehingga auditor dapat memberikan kesimpulan atas opini yang harus diberikan atas laporan keuangan yang diauditnya.

Carcello et al., (1995), perusahaan perusahaan besar tidak terlalu cenderung gagal, dan auditor akan ragu ragu mengeluarkan opini going concern untuk klien besar karena kekhawatiran akan kehilangan fee audit yang signifikan yang dihasilkan dari klien besar. Mutchler dan Williams, (1990), menunjukkan bahwa rata rata perusahaan kecil lebih rentan terhadap kebangkrutan daripada perusahaan besar, perusahaan yang lebih besar mungkin lebih mampu karena memiliki keunggulan kompetitif atas perusahaan perusahaan kecil (skala ekonomi) atau mungkin lebih mampu untuk mendapatkan pembiayaan tambahan dan mengalokasikan sumber daya dalam rangka untuk mencegah kebangkrutan.

Alim, et al., (2007), menggunakan pergantian auditor sebagai indikator dari independensi. Independensi merupakan sikap yang diharapkan dari seorang akuntan publik untuk tidak mempunyai kepentingan pribadi dalam pelaksanaan tugasnya yang bertentangan dengan prinsip integritas dan objektivitas. Nicholas dan Price, (1976), menemukan bahwa ketika auditor dan manajemen tidak mencapai kata sepakat dalam aspek kinerja, maka kondisi ini dapat mendorong manajemen untuk memaksa auditor melakukan tindakan yang melawan standar, termasuk dalam pemberian opini.

Keputusan Ketua BAPEPAM LK (No Kep-643/BL/2012) menyatakan bahwa komite audit adalah komite yang dibentuk oleh dan bertanggung jawab kepada dewan komisaris dalam membantu melaksanakan tugas dan fungsi dewan komisaris. Keberadaan komite audit dalam suatu perusahaan memberikan pengawasan yang lebih terhadap kinerja manajemen perusahaan dan memberikan informasi yang akurat dan tepat serta membantu dewan komisaris dalam menganalisis laporan keuangan perusahaan. Wandhani (2009), menambahkan dengan adanya komite audit dalam suatu perusahaan, maka proses pelaporan keuangan perusahaan akan termonitor dengan baik. Sesuai dengan perannya, komite audit ini akan memastikan bahwa perusahaan menerapkan prinsip prinsip akuntansi yang akan menghasilkan informasi keuangan yang akurat dan berkualitas. 
Berdasarkan pemaparan di atas, maka dilakukan penelitian dengan tujuan untuk mengetahui dan menganalisis pengaruh debt default, kesulitan keuangan, reputasi auditor, opini audit tahun lalu, ukuran perusahaan, pergantian auditor, dan ukuran komite audit terhadap opini going concern.

\section{METODE}

\section{Pendekatan Penelitian}

Pendekatan penelitian ini menggunakan pendekatan kuantitatif adalah menguji teori, membangun fakta, menunjukkan hubungan dan pengaruh serta perbandingan antarvariabel, memebrikan deskripsi statistik, menafsir dan meramalkan hasilnyayaitu mementingkan adanya variabel-variabel sebagai objek penelitian, dan variabel-variabel tersebut harus didefinisikan dalam bentuk operasionalisasi dari masingmasing variabel (Siregar, 2013).

\section{Objek Penelitian}

Variabel dalam penelitian ini terdiri dari variabel dependen dan independen. Variabel dependen merupakan pemberian opini going concern kemudian variabel independen yakni debt default, kesulitan keuangan, reputasi auditor, opini audit tahun sebelumnya, ukuran perusahaan, pergantian auditor, dan ukuran komite audit. Pengujian variabel independen untuk melihat pengaruhnya terhadap variabel dependen dilakukan dengan cara dua tahap yakni sampel perusahaan yang mengalami kesulitan keuangan, dan rugi komprehensif.

\section{Definisi Operasional}

Variabel variabel penelitian dapat diuraikan sebagai berikut:

\section{Opini Audit Going Concern}

Opini audit going concern diukur dengan variabel dummy kode 1; jika perusahaan menerima opini audit going concern dan 0 ; jika lainnya

\section{Debt Default}

Debt default diukur dengan variabel dummy kode 1 ; jika perusahaan mengalami debt default dan 0 ; jika lainnya.

\section{Kesulitan Keuangan}

Kategori perusahaan yang mengalami financial distress menggunakan model prediksi kebangkrutan ZScore Altman Revised dengan formula berikut ini.

$$
\mathrm{Z}=0.717 \mathrm{Z} 1+0.874 \mathrm{Z} 2+3.107 \mathrm{Z} 3+
$$

$0.420 \mathrm{Z} 4+0.998 \mathrm{Z} 5$

Dimana, $\mathrm{Z1}$ = working capital $/$ total aset, $\mathrm{Z} 2$ = retained earnings $/$ total aset, $\mathrm{Z} 3=\quad$ earning before interest and taxes / total aset, Z4 = book value of equity / book value of debt, dan Z5 = sales / total aset

Model Altman memberikan 1.20 untuk perusahaan yang berpotensi bangkrut dan diatas 2.90 untuk perusahaan sehat dan antara 1.20 sampai 2.90 merupakan grey area dimana kemungkinan perusahaan akan bangkrut atau tidak. Kondisi keuangan perusahaan diukur dengan menggunakan skala rasio hasil perhitungan ZScore Altman.

\section{Reputasi Auditor}

Reputasi auditor diukur dengan variabel dummy kode 1; jika perusahaan berafiliasi dengan big four dan 0; jika lainnya.

5. Opini Audit Tahun Sebelumnya Opini audit tahun sebelumnya diukur dengan variabel dummy kode 1; jika perusahaan 
menerima opini going concern tahun sebelumnya dan 0; jika lainnya

\section{Ukuran Perusahaan}

Ukuran perusahaan diukur dengan menggunakan skala nominal yakni nilai rupiah penuh dari total asset.

\section{Pergantian Auditor}

Pergantian auditor diukur dengan variabel dummy kode 1; jika perusahaan melakukan pergantian auditor dan 0; jika lainnya

8. Ukuran Komite Audit

Ukuran komite audit diukur dengan menggunakan skala nominal yakni jumlah komite audit.

\section{Tempat Penelitian}

Penelitian ini akan dilakukan di Galeri Investasi STIEM Bongaya dan akan mengambil informasi dari perusahaan yang terdaftar di Bursa Efek Indonesia (BEI) tahun 2012 - 2014.

\section{Sampel}

Teknik penarikan sampel dalam penelitian ini menggunakan purposive sampling yakni teknik pengambilan sampel dengan menggunakan kriteria tertentu (Sugiyono, 2007). Kriteria yang digunakan dalam pengambilan sampel penelitian mencakup pada perusahaan yang mengalami kesulitan keuangan, dan rugi komprehensif yang diuji secara berbeda.

\section{Metode Pengumpulan Data}

Metode pengumpulan data dalam penelitian ini yakni data laporan keuangan yang telah diaudit oleh auditor independen dan laporan opini audit independen yang diperoleh dengan menggunakan teknik dokumentasi.

\section{Metode Analisis Data}

Metode analisis data yang digunakan pada penelitian ini adalah analisis regresi logistic dengan alat bantu program SPSS versi 22.0.

\section{HASIL DAN PEMBAHASAN}

Penelitian ini menguji secara terpisah sampel perusahaan yang mengalami kesulitan keuangan dan rugi komprehensif, Hal ini dilakukan karena sampel yang dihasilkan berbeda. Sampel kesulitan keuangan akan menguji variabel independen debt default, reputasi auditor, opini audit tahun lalu, ukuran perusahaan, pergantian auditor, dan ukuran komite audit. Sedangkan rugi komprehensif menggunakan debt default, kesulitan keuangan, reputasi auditor, opini audit tahun sebelumnya, ukuran perusahaan, pergantian auditor, dan ukuran komite audit. Berikut hasil pengujian hipotesis.

\section{Perusahaan Yang Mengalami Kesulitan}

\section{Keuangan}

Debt Default menunjukkan nilai koefesien positif sebesar 2.046 dengan tingkat signifikansi sebesar 0.031 dan lebih kecil dari 0.05 atau $(0.031<0.05)$. Sehingga dapat dinyatakan bahwa debt default berpengaruh positif terhadap pemberian opini going concern. Reputasi auditor menunjukkan nilai koefesien positif sebesar 0.220 dengan tingkat signifikansi sebesar 0.799 dan lebih besar dari 0.05 atau $(0.799>0.05)$. Sehingga dapat dinyatakan bahwa reputasi auditor tidak berpengaruh terhadap pemberian opini going concern. Opini audit tahun sebelumnya menunjukkan nilai koefesien positif sebesar 3.805 dengan tingkat signifikansi sebesar 0.000 dan lebih kecil dari 0.05 atau $(0.000<0.05)$. Sehingga dapat 
dinyatakan bahwa opini audit tahun sebelumnya berpengaruh positif terhadap pemberian opini going concern.

Ukuran perusahaan menunjukkan nilai koefesien positif sebesar 0.000 dengan tingkat signifikansi sebesar 0.002 dan lebih kecil dari 0.05 atau $(0.002<0.05)$. Sehingga dapat dinyatakan bahwa ukuran perusahaan berpengaruh positif terhadap pemberian opini going concern. Pergantian auditor menunjukkan nilai koefesien negatif sebesar -0.114 dengan tingkat signifikansi sebesar 0.875 dan lebih besar dari 0.05 atau $(0.875>0.05)$. Sehingga dapat dinyatakan bahwa pergantian auditor tidak berpengaruh terhadap pemberian opini going concern. Ukuran komite audit menunjukkan nilai koefesien positif sebesar 0.099 dengan tingkat signifikansi sebesar 0.753 dan lebih besar dari 0.05 atau $(0.753>0.05)$. Sehingga dapat dinyatakan bahwa ukuran komite audit tidak berpengaruh terhadap pemberian opini going concern.

\section{Perusahaan Yang Mengalami Rugi}

Komprehensif

Debt Default menunjukkan nilai koefesien positif sebesar 1.680 dengan tingkat signifikansi sebesar 0.046 dan lebih kecil dari 0.05 atau $(0.046<0.05)$. Sehingga dapat dinyatakan bahwa debt default berpengaruh positif terhadap pemberian opini going concern. Kesulitan keuangan menunjukkan nilai koefesien negatif sebesar -0.447 dengan tingkat signifikansi sebesar 0.018 dan lebih kecil dari 0.05 atau $(0.018<0.05)$. Sehingga dapat dinyatakan bahwa kesulitan keuangan berpengaruh negatif terhadap pemberian opini going concern. Reputasi auditor menunjukkan nilai koefesien positif sebesar 0. 315 dengan tingkat signifikansi sebesar 0.717 dan lebih besar dari 0.05 atau $(0.717>0.05)$. Sehingga dapat dinyatakan bahwa reputasi auditor tidak berpengaruh terhadap pemberian opini going concern. Opini audit tahun sebelumnya menunjukkan nilai koefesien positif sebesar 5.426 dengan tingkat signifikans sebesar 0.000 dan lebih kecil dari 0.05 atau $(0.000<0.05)$. Sehingga dapat dinyatakan bahwa opini audit tahun sebelumnya berpengaruh positif terhadap pemberian opini going concern.

Ukuran perusahaan menunjukkan nilai koefesien positif sebesar 0.000 dengan tingkat signifikansi sebesar 0.029 dan lebih kecil dari 0.05 atau $(0.029<0.05)$. Sehingga dapat dinyatakan bahwa ukuran perusahaan berpengaruh positif terhadap pemberian opini going concern. Pergantian auditor menunjukkan nilai koefesien negatif sebesar -1.029 dengan tingkat signifikansi sebesar 0.230 dan lebih besar dari 0.05 atau $(0.230>0.05)$. Sehingga dapat dinyatakan bahwa pergantian auditor tidak berpengaruh terhadap pemberian opini going concern. Ukuran komite audit menunjukkan nilai koefesien positif sebesar 0.948 dengan tingkat signifikansi sebesar 0.356 dan lebih besar dari 0.05 atau $(0.356>0.05)$. Sehingga dapat dinyatakan bahwa ukuran komite audit tidak berpengaruh terhadap pemberian opini going concern.

Penelitian menunjukkan bahwa debt default berpengaruh positif terhadap pemberian opini going concern pada perusahaan yang mengalami kesulitan keuangan dan rugi komprehensif. Penelitian ini mendukung 
penelitian terdahulu seperti Chen \& Church (1992), dan Carcello \& Neal (2000), yang menemukan pengaruh signifikan debt default terhadap pemberian opini going concern. Praptitorini \& Januarti (2007), dan Ramadhany (2004), menemukan debt default berpengaruh positif terhadap opini going concern. Hal ini berarti bahwa salah satu penyebab auditor mengeluarkan opini going concern karena masalah pembiayaan dengan salah satu kategorinya debt default, dan bahwa auditor harus hati hati meneliti kemampuan perusahaan dalam memenuhi kewajibannya dalam mengambil keputusan opini going concern.

Penelitian selanjutnya menunjukkan kesulitan keuangan berpengaruh positif negatif terhadap pemberian opini going concern pada perusahaan yang mengalami rugi komprehensif. Pendley (1998); Carcello \& Neal (2000), dan Margaretta \& Saputra (2005), yang menemukan terdapat pengaruh positif kesulitan keuangan terhadap pemberian opini going concern. Hal ini menunjukkan bahwa auditor hampir tidak pernah mengeluarkan opini going concern pada perusahaan yang tidak mengalami financial distress. Atau hasil yang menunjukkan hubungan yang positif signifikan antara probabilitas menerima opini going concern dan tingkat keparahan sinyal kesulitan keuangan.

Reputasi auditor tidak berpengaruh terhadap pemberian opini going concern pada perusahaan yang mengalami kesulitan keuangan dan rugi komprehensif. Carcello \& Neal (2000), menemukan reputasi auditor tidak berpengaruh signifikan terhadap pemberian opini going concern. Setyarno et al (2006); Praptitorini \& Januarti (2007), dan Rahman \& Siregar (2011), yang menemukan reputasi auditor tidak berpengaruh positif terhadap pemberian opini going concern. Hal ini berarti Fee audit yang tinggi perusahaan bayarkan apabila diaudit oleh KAP afiliasi big four membuat perusahaan yang mengalami kesulitan baik keuangan maupun non keuangan memilih KAP yang tidak afiliasi dengan big four sehingga fee audit yang dibayarkan rendah.

Opini audit tahun sebelumnya berpengaruh positif terhadap pemberian opini going concern pada perusahaan yang mengalami kesulitan keuangan dan rugi komprehensif. Carcello \& Neal (2000), menemukan opini audit tahun sebelumnya berpengaruh signifikan terhadap pemberian opini going concern. Setyarno et al (2006); Puji (2007); Rahman \& Siregar (2011); Praptitorini \& Januarti (2007), dan Ramadhany (2004), menemukan pengaruh positif, opini audit tahun sebelumnya dengan pemberian opini going concern. Hal ini menunjukkan bahwa perusahaan yang menerima opini going concern tahun sebelumnya merupakan indikasi kuat bahwa perusahaan bermasalah dan selama auditor memperhatikan hal ini, maka kemungkinan perusahaan akan memiliki probabilitas tinggi untuk menerima opini going concern.

Ukuran perusahaan berpengaruh positif terhadap pemberian opini going concern pada perusahaan yang mengalami kesulitan keuangan dan rugi komprehensif. Chen \& Church (1992), dan Carcello \& Neal (2000), yang menemukan ukuran perusahaan berpengaruh signifikan terhadap pemberian opini going concern. Pendley (1998), dan Ramadhany (2004), menemukan pengaruh negatif ukuran perusahaan 
terhadap pemberian opini going concern. Hal ini menunjukkan bahwa auditor dalam menerbitkan opini going concern memperhatikan ukuran perusahaan karena perusahaan besar memiliki resiko gagal yang rendah karena memiliki keunggulan kompetitif dari pada perusahaan yang lebih kecil, dan menunjukkan bahwa rata rata perusahaan kecil lebih rentan terhadap kebangkrutan daripada perusahaan besar.

Pergantian auditor tidak berpengaruh terhadap pemberian opini going concern pada perusahaan yang mengalami kesulitan keuangan dan rugi komprehensif. Pendley (1998), yang menemukan bahwa pergantian auditor tidak berpengaruh terhadap pemberian opini going concern. Hal ini menunjukkan bahwa Fee audit yang tinggi dan kualitas audit yang dirasakan perusahaan juga dapat menjadi penyebab perusahaan melakukan pergantian auditor. Selain itu regulasi BAPEPAM-LK yang mengatur Kantor Akuntan Publik paling lama untuk 6 (enam) tahun buku berturut-turut dan oleh seorang akuntan paling lama untuk 3 (tiga) tahun buku berturut-turut dapat menyebabkan perusahaan melakukan pergantian auditor.

Ukuran komite audit tidak berpengaruh terhadap pemberian opini going concern pada perusahaan yang mengalami kesulitan keuangan dan rugi komprehensif. Carcello \& Neal (2000), yang menemukan bahwa ukuran komite audit tidak berpengaruh terhadap pemberian opini going concern. Puji (2007), yang komposisi komite audit tidak berpengaruh negatif terhadap pemberian opini going concern. Hal ini menunjukkan bahwa meskipun peran komite audit yang akan memastikan bahwa perusahaan menerapkan prinsip prinsip akuntansi yang akan menghasilkan informasi keuangan yang akurat dan berkualitas, dan komite audit bertugas membantu dewan komisaris untuk memonitor proses pelaporan keuangan oleh manajemen untuk meningkatkan kredibilitas laporan keuangan. Keberadaan komite audit dengan tugas dan tanggungjawabnya diatas tidak dapat memberikan respon yang positif terhadap kualitas audit perusahaan.

\section{KESIMPULAN DAN SARAN}

Kesimpulan dalam penelitian ini yakni debt default berpengaruh positif terhadap pemberian opini going concern pada perusahaan yang mengalami kesulitan keuangan dan rugi komprehensif. Kesulitan keuangan berpengaruh negatif terhadap pemberian opini going concern pada perusahaan yang mengalami rugi komprehensif. Reputasi auditor tidak berpengaruh terhadap pemberian opini going concern pada perusahaan yang mengalami kesulitan keuangan, dan rugi komprehensif. Opini audit tahun lalu berpengaruh positif terhadap pemberian opini going concern pada perusahaan yang mengalami kesulitan keuangan dan rugi komprehensif. Ukuran perusahaan berpengaruh negatif terhadap pemberian opini going concern pada perusahaan yang mengalami kesulitan keuangan, dan rugi komprehensif. Pergantian auditor tidak berpengaruh terhadap pemberian opini going concern pada perusahaan yang mengalami kesulitan keuangan, dan rugi komprehensif. Ukuran komite audit tidak berpengaruh negatif terhadap pemberian opini going concern bagi perusahaan yang mengalami kesulitan keuangan, dan rugi komprehensif.

Saran dalam penelitian ini yakni kriteria penarikan sampel untuk perusahaan yang 
mengalami kesulitan keuangan sebaiknya menggunakan model prediksi kebangkrutan yang dapat diuji pada seluruh sektor perusahaan yang terdapat di Bursa Efek Indonesia (BEI). Variabel yang digunakan untuk menguji pemberian opini going concern sebaiknya ditambah seperti struktur kepemilikan, tenure audit, perusahaan dalam tahap pengembangan, rasio rasio keuangan baik rasio kombinasi seperti the zmijeski model 1984, the altman model 1968, revised altman model 1993, the springate model 1978 maupun rasio tunggal seperti likiuditas, profitabilitas, dan solvabilitas.

\section{DAFTAR RUJUKAN}

Arens et al. (2008). Auditing dan Jasa Inssurance (Pendekatan Terintegrasi) Edisi Keduabelas. Jilid Satu. Salemba Empat: Jakarta.

Bradbury M.E. et al. (2004). Board Characteristics, Audit Committee Characteristics and Abnormal Accruals. Working Paper. United New Zealand and National University of Singapore.

Carcello J.V. \& Neal J.L. (2000). Audit Committee Composition and Auditor Reporting. Accounting Review. Vol 75 No. $4 \mathrm{hlm}$ 453-467

Chen K.C. \& Church B.K. (1992). Default on Debt Obligations and the Issuance of Going Concern Report. Auditing: Journal Practice and Theory. Fall. Hlm 30-49

DeAngelo L. (1981). Auditor Independence, "low balling" and Disclosure Regulation. Journal of Accounting and Economics. (August). hlm 113-127

Margaretta F. \& Saputra. (2005). Opini Going Concern: Kajian Berdasarkan Model Prediksi Kebangkrutan, Pertumbuhan Perusahaan, dan Reputasi Kantor Akuntan Publik (Studi Pada Emiten Bursa Efek Jakarta). Simposium Nasional Akuntansi VIII Solo. hlm 966-978

Institut Akuntan Publik Indonesia IAPI. (2011). Standart Profesional Akuntan Publik. Penerbit Salemba Empat; Jakarta

Jensen M.C \& Meckling W.H. (1976). Theory of the Firm, Managerial Behaviour; Agency
Cost, and Ownership Structure. Journal of Financial Economics 3, hlm 35-60

Junaidi \& Hartono J. (2010). Faktor Non Keuangan pada Opini Going Concern. Simposium Nasional Akuntansi XIII. Purwokerto

Menon K. \& Williams D. (2010). Investor Reaction to Going Concern Audit Report. The Accounting Review. Vol. 85. No. 6: hlm 2075-2105

Mutchler J.F. et al. (1997). The Influence of Contrary Information and Mitigating Factors on Audit Report Decisions on Bankrupt Companies. Jornal of Accounting Research. Autumn

Palmrose. (1988). An Analysis of Auditor Litigation and Audit Service Quality. The Accounting Review. Vol 63, No 1; hlm 5573

Pendley J.A. (1998). Industry Specialization in the Auditors Going Concern Opinion Decision. Accounting Enguiries. Vol 7 No. 2

Puji R. (2007). Assesing Going Concern Opinion: A Study Based on Financial and Non Financial Informations. Simposium Nasional Akuntansi X Makassar

Praptitorini D.M. \& Januarti I. (2007). Analisis Pengaruh Kualitas Audit, Debt Default dan Opinion Shopping Terhadap Penerimaan Opini Going Concern. Simposium Nasional Akuntansi $X$ Makassar

Rahman A. \& Siregar B. (2011). Faktor Faktor Yang Mempengaruhi Kecendrungan Penerimaan Opini Audit Going Concern Pada Perusahaan Manufaktur Yang Terdaftar di Bursa Efek Indonesia. Simposium Nasional Akuntansi XIV Banda Acer.

Ramadhany A. (2004). Analisis Faktor - Faktor Yang Mempengaruhi Penerimaan Opini Going Concern Pada Perusahaan Manufaktur Yang Mengalami Financial Distress Di Bursa Efek Jakarta. Tesis S2, UniversitasDiponegoro, Semarang. Tidak Dipublikasikan.

Setyarno E.B. et al. (2006). Pengaruh Kualitas Audit, Kondisi Keuangan Perusahaan, Pertumbuhan Perusahaan Terhadap Opini Audit Going Concern. Simposium Nasional Akuntansi IX Padang

Sugiyono. (2007). Metode Penellitian Bisnis. Alfabeta; Bandung 